\title{
A Complete Assessment of Carbon Stocks in Above and Belowground Biomass Components of a Hybrid Eucalyptus Plantation in Southern Brazil
}

\author{
Márcio Viera ${ }^{1, * \mathbb{C}}$ and Roque Rodríguez-Soalleiro ${ }^{2}$ \\ 1 UFSM Polytechnic School, Federal University of Santa Maria (UFSM), Santa Maria 97105900, Brazil \\ 2 Department of Vegetal Production, University of Santiago de Compostela (USC), 27154 Lugo, Spain \\ * Correspondence: marcio.viera@ufsm.br; Tel.: +55-55-98412-9050
}

Received: 14 May 2019; Accepted: 26 June 2019; Published: 27 June 2019

\begin{abstract}
Hybrid eucalypt clones are grown for fiber production worldwide and to provide an ecosystem service that can store atmospheric carbon at a very fast rate. This study assessed the carbon stocks in the soil and various tree fractions in a 10-year-old plantation of Eucalyptus urophylla S.T. Blake $\times$ Eucalyptus globulus Labill. in Southern Brazil. Four experimental plots were established, and an inventory of Eucalyptus trees was conducted by considering five diametric classes. Three trees in each diametric class were harvested for biomass and carbon quantification. The understory biomass of native trees was quantified in five subplots and the litter was quantified in 16 subplots. Organic $C$ was quantified in the soil (SOC) and roots (diameter $\leq 0.5 \mathrm{~cm}$ ) to a depth of $100 \mathrm{~cm}$. The C concentration in the different biomass fractions of the eucalyptus trees were $55.7 \%( \pm 0.6), 50.4 \%( \pm 0.4), 49.5 \%( \pm 0.6)$ and $45.4 \%( \pm 0.9)$ for leaves, branches, wood and bark, respectively. The $C$ concentrations in the understory fractions were $51.4 \%( \pm 1.0)$ for the canopy and $50.0 \%( \pm 0.9)$ for the stem. The carbon concentration in the fine root biomass was $45.7 \%( \pm 1.4)$. Soil C concentrations were $1.23 \%( \pm 0.32)$, $0.97 \%( \pm 0.10), 0.45 \%( \pm 0.14)$, and $0.24 \%( \pm 0.10)$ for depths of $0-25,25-50,50-75$, and $75-100 \mathrm{~cm} . \mathrm{C}$ was allocated in: (a) the trees (aboveground fraction $=118.45 \mathrm{Mg} \mathrm{ha}^{-1}$ and belowground fraction $\left.=30.06 \mathrm{Mg} \mathrm{ha}^{-1}\right)$, (b) the understory $=1.44 \mathrm{Mg} \mathrm{ha}^{-1}$, (c) the litter $=8.34 \mathrm{Mg} \mathrm{ha}^{-1}$, and (d) the soil (without roots) $=99.7 \mathrm{Mg} \mathrm{ha}^{-1}$. The share of total C stock $\left(\mathrm{a}+\mathrm{b}+\mathrm{c}+\mathrm{d}=258.0 \mathrm{Mg} \mathrm{ha}^{-1}\right)$ was similar in the aboveground $(49.7 \%)$ and belowground $(50.3 \%)$ fractions, thus indicating a very high rate of $C$ sequestration in the biomass. Eucalyptus plantations in Brazil are fast growing (for this study $=36.7 \mathrm{~m}^{3} \mathrm{ha}^{-1}$ year $^{-1}$ ) and contribute to intense carbon sequestration in above and belowground biomass (14.8 $\mathrm{Mg} \mathrm{ha}^{-1}$ year $^{-1}$ ).
\end{abstract}

Keywords: carbon fixation; Eucalyptus stands; soil carbon; biomass carbon; allometric equations

\section{Introduction}

Demand for wood products has grown strongly in recent years, thereby increasing interest in the use of land for fast-growing tree plantations. In Brazil, the total area covered by forest plantations in 2017 was about $9.8 \mathrm{M}$ ha [1], yielding 91\% of the wood destined for industrial purposes [2]. Eucalyptus was first introduced to Brazil more than 150 years ago. Plantations of the species now cover an area of $7.4 \mathrm{M}$ ha and represent $75.2 \%$ of all forest plantations in the country [1] and yield on average $39 \mathrm{~m}^{3} \mathrm{ha}^{-1}$ year $^{-1}$ [2]. Eucalyptus has been planted extensively in Brazil in the past 10 years, with an increase of about $70 \%$ in plantations of the species in the period. Short rotations are used for pulpwood (6-7 years) and slightly longer rotations for solid timber (12-15 years). The main products are pulp, paper, wood panels, laminate flooring, plywood panels, furniture, other solid wood products, and charcoal and biomass for energy purposes [2]. 
Forest plantations play an important role in the global carbon cycle [3,4], as when forests grow, carbon is removed from the atmosphere and stored in the plants [5-7]. New forest establishment is of ecological, environmental, social, and economic value [6] and results in large amounts of $C$ being sequestered [7-9], although trade-offs involving the impacts on hydrology and biogeochemistry should be taken into account [10]. Plantations can maximize carbon sequestration, but also have adverse side effects such as reduced stream flow [11] and decreased soil $\mathrm{pH}$ and base saturation [10].

Increasing the carbon stock depends on the biomass allocation of each species and the $C$ concentrations in each component [12]. Biomass allocation depends on the resources available at the site as well as the type of management [13], stand age [3,9], and rotation length [14]. Likewise, the accumulation of soil carbon depends on the type of land use $[15,16]$, soil chemical and physical properties [8], climatic conditions [7], net primary productivity, fertilization, site preparation, and soil drainage [17].

The transformation of the current fossil fuel-based energy generation systems to sustainable and renewable energy (RE)-based systems by 'carbon-neutral' alternatives has been reported to be essential [18]. Brazil is one of 97 developing countries that have included land use, land use change and forestry (LULUCF) in their nationally determined contributions (NDCs). However, the LULUCF sector requires scientific data to ensure that the national reports are consistent, complete, and comparable [19]. Several studies have estimated the carbon stocks in Eucalyptus stands (i.e., [20-24], but there is still a lack of studies considering all ecosystem components in the plantations including both above and belowground components such as the tree biomass and soil fraction. Accurate methods of estimating carbon stocks in forest stands are required for building and validating regional models [4]. In addition, the understory and the litter layer must be considered additional pools for estimating stand carbon sequestration [25]. Hybrid eucalypt clones in Brazil grow very quickly and thus have a high capacity to fix atmospheric carbon. Carbon stocks can be estimated in forestry plantations by biomass quantification, subsequent determination of $C$ concentration, and fitting allometric equations.

The main goal of this study was to carry out a complete assessment of carbon stocks in a eucalypt plantation, close to the rotation age, and thus with stabilized $C$ concentrations. An additional aim was to compare the carbon concentrations in above and belowground biomass components and the carbon stock in the soil of a 10-year-old hybrid plantation of Eucalyptus urophylla $\times$ Eucalyptus globulus in Southern Brazil.

\section{Materials and Methods}

\subsection{Site and Stand Description}

The study was conducted in a 10-year-old Eucalyptus urophylla $\times$ E. globulus stand close to harvesting age ( $30^{\circ} 10^{\prime} 31.21^{\prime \prime} \mathrm{S}$ and $51^{\circ} 36^{\prime} 17.85^{\prime \prime} \mathrm{W}$; elevation: $175 \mathrm{~m}$ a.s.l.). According to the Köppen system, the climate is classified as $\mathrm{Cfa}$ (humid subtropical). Average temperatures range from $13.4^{\circ} \mathrm{C}$ in the coldest month to $24.3^{\circ} \mathrm{C}$ in the hottest month, with an average annual rainfall of $1600 \mathrm{~mm}$ [26]. The soil is classified as an Acrisol, according to the Word Reference Base [27], and soil chemical and physical properties include a low cation exchange capacity, low base saturation, and acidic conditions (Table 1).

Eucalyptus seedlings were planted after minimum tillage in the planting line in July 2001. The stand was established with a spacing of $3.5 \mathrm{~m} \times 2.5 \mathrm{~m}$. Fertilizer was applied when the seedlings were planted, with $300 \mathrm{~kg} \mathrm{ha}^{-1}$ of reactive phosphate and $100 \mathrm{~g}$ seedlings ${ }^{-1}$ of 06-30-06 $\left(\mathrm{N}-\mathrm{P}_{2} \mathrm{O}_{5}-\mathrm{K}_{2} \mathrm{O}\right)$. After planting, fertilizer was applied twice, once in the third month and again in the twelfth month, with 15-05-30 (N-P $\left.\mathrm{P}_{5}-\mathrm{K}_{2} \mathrm{O}\right) 100$ g plant $^{-1}$. 
Table 1. Soil chemical and physical properties of the Eucalyptus urophylla $\times$ Eucalyptus globulus plantation ( $n=9$ repetitions), 10 years after establishment.

\begin{tabular}{|c|c|c|c|c|c|c|c|c|c|c|}
\hline \multirow{2}{*}{$\begin{array}{c}\text { Depth } \\
\text { (cm) }\end{array}$} & O.M. & $\mathbf{N}$ & \multirow{2}{*}{$\underset{\left(\mathrm{H}_{2} \mathrm{O}\right)}{\mathrm{pH}}$} & $\mathrm{Ca}$ & Mg & Al & $\mathrm{Na}$ & CEC $_{\text {effect. }}$ & \multicolumn{2}{|c|}{ BS } \\
\hline & \multicolumn{2}{|c|}{$(\%)$} & & \multicolumn{5}{|c|}{$\mathrm{cmol}_{\mathrm{c}} \mathrm{dm}^{-3}$} & \multicolumn{2}{|c|}{$\%$} \\
\hline $0-25$ & 2.46 & 0.08 & 4.64 & 0.34 & 0.41 & 4.13 & 0.28 & 7.47 & \multicolumn{2}{|c|}{20.68} \\
\hline $25-50$ & 1.94 & 0.07 & 4.73 & 0.25 & 0.42 & 5.38 & 0.25 & 6.09 & \multicolumn{2}{|c|}{21.56} \\
\hline $50-75$ & 0.90 & 0.03 & 4.81 & 0.24 & 0.38 & 4.83 & 0.22 & 4.72 & \multicolumn{2}{|c|}{23.78} \\
\hline 75-100 & 0.48 & 0.02 & 4.87 & 0.24 & 0.30 & 4.45 & 0.30 & 8.02 & \multicolumn{2}{|c|}{18.53} \\
\hline \multirow{2}{*}{$\begin{array}{c}\text { Depth } \\
(\mathrm{cm})\end{array}$} & $\mathbf{P}$ & $\mathbf{K}$ & Sand & Silt & Clay & $\begin{array}{l}\text { Micro } \\
\text { Porosity }\end{array}$ & $\begin{array}{c}\text { Macro } \\
\text { Porosity }\end{array}$ & $\begin{array}{c}\text { Total } \\
\text { Porosity }\end{array}$ & SD & PD \\
\hline & \multicolumn{2}{|c|}{ ppm } & \multicolumn{3}{|c|}{$\%$} & \multicolumn{3}{|c|}{$\%$} & \multicolumn{2}{|c|}{$\mathrm{g} \mathrm{cm}^{-3}$} \\
\hline $0-25$ & 1.32 & 52.10 & 46.2 & 11.6 & 42.2 & 18.06 & 30.17 & 48.23 & 1.41 & 2.74 \\
\hline $25-50$ & 0.64 & 54.07 & 23.5 & 13.8 & 62.7 & 36.16 & 16.45 & 52.62 & 1.33 & 2.81 \\
\hline $50-75$ & 0.61 & 40.34 & 29.8 & 19.4 & 50.8 & 36.79 & 15.00 & 51.79 & 1.37 & 2.84 \\
\hline 75-100 & 0.51 & 25.89 & 49.9 & 25.7 & 24.4 & 36.91 & 11.63 & 48.54 & 1.46 & 2.84 \\
\hline
\end{tabular}

Where O.M. = organic matter, $\mathrm{CEC}=$ cation exchange capacity, $\mathrm{BS}=$ base saturation, $\mathrm{SD}=$ soil density, and $\mathrm{PD}=$ particle density.

\subsection{Tree Sampling and Measurements}

Four inventory plots $(35 \mathrm{~m} \times 20 \mathrm{~m})$ were systematically established in a 10-year-old Eucalyptus urophylla $\times$ E. globulus stand. The diameter at breast height $(\mathrm{DBH})$ and total height $(\mathrm{H})$ were measured in all of the trees in each plot, and the density of live trees was calculated. The structure of the stand was very homogeneous in terms of density and tree size, with a coefficient of variation of tree height of only $9 \%$ (Table 2). Predictive equations were used to calculate stand variables such as basal area, standing volume, and leaf area index (LAI). The mean annual increment was $36.7 \mathrm{~m}^{3} \mathrm{ha}^{-1} \mathrm{year}^{-1}$, which is an intermediate level of productivity in the Brazilian context (Table 2). Based on the stand DBH distribution, trees were included in five diameter classes: 9.1-13.0; 13.1-17.0; 17.1-21.0; 21.1-25.0, and $25.1-29.0 \mathrm{~cm}$, which corresponded to $5 \%, 18 \%, 32 \%, 37 \%$, and $9 \%$ in relation to the total number of trees.

Table 2. Dendrometric variables in the 10-year-old Eucalyptus urophylla $\times$ Eucalyptus globulus stand.

\begin{tabular}{|c|c|c|c|c|c|c|c|}
\hline Variables & $\begin{array}{c}n \\
\left(\text { trees } \text { plot }^{-1}\right)\end{array}$ & $\begin{array}{c}N \\
\text { (trees ha }^{-1} \text { ) }\end{array}$ & $\begin{array}{l}\text { Basal Area } \\
\left(\mathrm{m}^{2} \mathrm{ha}^{-1}\right)\end{array}$ & DBH (cm) & H (m) & $V\left(m^{3} h a^{-1}\right)$ & $\begin{array}{c}\text { LAI } \\
\left(\mathrm{m}^{2} \mathrm{~m}^{-2}\right)\end{array}$ \\
\hline$\mu$ & 73 & 1043 & 34.56 & 20.2 & 28.7 & 366.9 & 2.55 \\
\hline$\sigma$ & 3.0 & 42.9 & 2.61 & 4.1 & 2.6 & 36.2 & 0.15 \\
\hline
\end{tabular}

$\mu=$ average; $\sigma=$ standard deviation.

Three trees in each diameter class were harvested for the evaluation of the carbon stocks in aboveground Eucalyptus biomass. For each of the 15 trees harvested, the aboveground biomass was separated into four components: leaves, branches, bark, and commercial wood (smaller diameter use $=6.0 \mathrm{~cm}$ ). Stems of diameter less than $6 \mathrm{~cm}$ were considered as branches.

The fresh weight of each tree component was measured and samples were taken to determine the dry weight and carbon contents. Wood and bark were sampled at three different points along the stem at relative heights of $0.25,0.5$, and 0.75 . Branches and leaves were sampled randomly throughout the canopy, considering a sampling intensity of $5 \%$ of the total amount in each tree. The samples were transported to the laboratory and dried in a convection oven at $70{ }^{\circ} \mathrm{C}$ for $72 \mathrm{~h}$ to determine the dry weight and estimate the total carbon per tree and component. 


\subsection{Understory and Litter Sampling}

Five $5 \times 5 \mathrm{~m}$ square plots were systematically established in the Eucalyptus stand to estimate the understory biomass. The positions of the understory plots followed the same rectangular grid used for the inventory plots, leading to a $3 \times 3$ layout of the plots. In each understory plot, all plants except for the eucalyptus trees were cut and separated into two biomass components: leaves and stem. The understory was composed of more than 15 native tree species of the Atlantic Forest Biome (mainly Cupania vernalis Cambess.) with individuals less than $3 \mathrm{~m}$ in height and most plants at the initial stage of regeneration. The carbon accumulated in the litter layer was determined in four samples from each of the four plots used to measure Eucalyptus DBH and height. A square frame with an area of $0.0625 \mathrm{~m}^{2}$ was used for this purpose. All of the organic material inside the frame was sampled for biomass estimation. To calculate the total carbon accumulated in the litter layer, we considered that the carbon content represented $50 \%$ of the dry matter.

\subsection{Root and Soil Sampling}

Carbon was measured in the fine roots (diameter $<2 \mathrm{~mm}$ ), medium roots with a diameter of 2-5 mm, medium roots of 5-10 $\mathrm{mm}$, and soil. Nine sampling points were established in the middle of each of the nine aforementioned plots and the method of root sampling in soil pits was applied. A $1.3 \mathrm{~m}$ deep trench was manually excavated at each sample point for the collection of roots and soil. In each trench, four soil layers were demarcated for sampling: $0-25 \mathrm{~cm}, 25-50 \mathrm{~cm}, 50-75 \mathrm{~cm}$, and 75-100 cm. A square frame with a side length of $10 \mathrm{~cm}$ was used to mark the area for excavating roots, yielding a volume of $2500 \mathrm{~cm}^{3}$ of soil for each sample at a $25 \mathrm{~cm}$ depth. The roots were separated from the soil by using water jets to wash the material through a set of sieves $(2.0 \mathrm{~mm}$ and $0.34 \mathrm{~mm}$ meshes). The roots were dried and the dry mass was weighed on an analytical balance (accuracy $10^{-4} \mathrm{~g}$ ). Soil samples were collected from the same trench for the analysis of organic carbon concentration and soil density.

The organic carbon in the different Eucalyptus components, understory, roots, and soil was determined on a dry weight basis in an element analyzer (Carlo Erba NA 1500, Milan, Italy).

As whole-tree excavation was not possible, the coarse root biomass was estimated for each inventoried tree by applying the model proposed by [28] for roots thicker than $10 \mathrm{~mm}$ in E. grandis $\times$ urophylla plantations of medium productivity including the stump:

$$
\mathrm{W}_{\mathrm{cr}}=0.0221 \mathrm{DBH}^{2.6017}(n=36)
$$

where $\mathrm{W}_{\mathrm{cr}}$ is the coarse root biomass $\left(\mathrm{kg}\right.$ tree $\left.{ }^{-1}\right)$ and $\mathrm{DBH}$ is the tree diameter in $\mathrm{cm}$. The $\mathrm{C}$ concentration determined for roots of 5-10 $\mathrm{mm}$ in this study was applied to the coarse roots.

\subsection{Data Calculation and Analysis}

The Eucalyptus aboveground carbon stock was estimated by fitting individual tree carbon regression models. The carbon content in different aboveground components of the Eucalyptus trees (leaves = $\mathrm{Cl}$, branches $=\mathrm{Cbr}$, bark $=\mathrm{Cb}$, and wood $=\mathrm{Cw}$ ) were considered as dependent variables. Different combinations of log-transformed independent variables were used: tree diameter (DBH), tree height $(\mathrm{H})$, and power combinations of these variables $\mathrm{DBH}^{\mathrm{x}} \mathrm{H}^{\mathrm{y}}$. A logarithmic transformation enabled the reflection of the relationships between variables, with the assumption of an underlying power function with a multiplicative error structure. The SPSS 13.0 application for Windows [29] was used for modeling. The goodness of fit of the models was evaluated by considering the coefficient of determination $\left(R^{2}\right.$ adjusted), standard error of estimate (Syx), and by the graphic evaluation of the relationships between the observed and estimated values. The amount of carbon per hectare was estimated by the regression of the data from the forest inventory and extrapolation based on the area of the plot.

The accumulated understory carbon was estimated by multiplying the carbon content in the dry biomass of each component per plot and extrapolated to a per hectare basis. For the litter layer, the dry biomass of each subplot $(n=16)$ was multiplied by the carbon content (assuming a 50\% 
content) and the amount was then extrapolated to a per hectare basis. For fine and medium roots, the biomass at each depth $(n=4)$ and at each point $(n=9)$ was multiplied by the corresponding carbon content, and extrapolated to a per hectare basis. For each soil sample, carbon stocks were calculated by multiplying soil carbon concentration by the bulk density $\left(\mathrm{kg} \mathrm{m}^{-3}\right)$ of each plot and by the depth of the soil layer. The bulk density was calculated by dividing the dry mass of soil $\left(105^{\circ} \mathrm{C}\right)$ by the volume of the sampling cylinder.

Duncan's test was used to identify significant differences in the values. Analysis of variance (ANOVA) was used to test the effects of the tree components and soil depth on carbon concentration in the Eucalyptus fine roots and soil. All statistical tests were performed with the SPSS 13.0 application for Windows [29] after checking the ANOVA assumptions.

\section{Results}

\subsection{Equations for Eucalyptus Aboveground Carbon Estimation}

The equations selected for estimating the carbon amounts in the biomass components are shown in Table 3. The value of the adjusted coefficient of determination was high, the value of the standard error of estimate was low, and the residuals were normally distributed. This demonstrates that the equations obtained by the stepwise procedure performed well in relation to predicting the carbon content per component and tree (Figure 1).
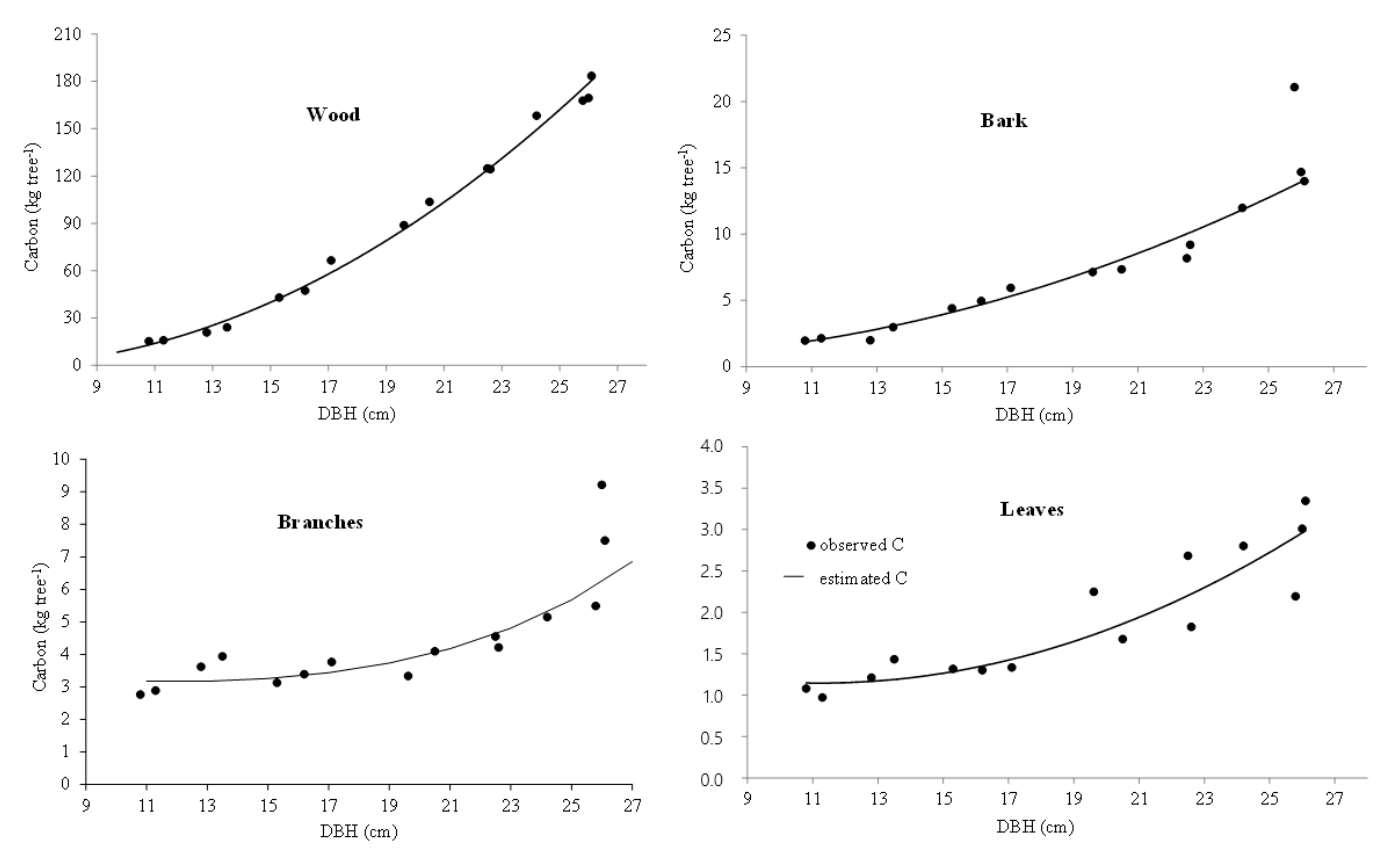

Figure 1. Observed and estimated amounts of carbon in the 10-year-old Eucalyptus urophylla $\times$ Eucalyptus globulus stand.

Table 3. Carbon equations for different components of the 10-year-old Eucalyptus urophylla $\times$ Eucalyptus globulus stand. $\mathrm{Cw}$ is carbon in wood $\left(\mathrm{kg}\right.$ tree $\left.{ }^{-1}\right), \mathrm{Cb}$ is carbon in bark $\left(\mathrm{kg}\right.$ tree $\left.{ }^{-1}\right), \mathrm{Cbr}$ is carbon in branches $\left(\mathrm{kg}\right.$ tree $\left.{ }^{-1}\right)$, and $\mathrm{Cl}$ is carbon in leaves $\left(\mathrm{kg}\right.$ tree $\left.^{-1}\right)$. DBH is diameter at breast height $(\mathrm{cm})$ and $\mathrm{H}$ is total tree height $(\mathrm{m})$.

\begin{tabular}{ccccc}
\hline Component & Equation & Prob $>\boldsymbol{F}$ & $\boldsymbol{R}^{2}$ ajd. & Syx \\
\hline Wood & Ln Cw $=-5.265+1.043 \ln \left(\mathrm{DBH}^{2} \times \mathrm{H}\right)$ & $<0.001$ & 0.996 & 0.0547 \\
Bark & nn Cb $=-4.855+2.299 \operatorname{lnDBH}$ & $<0.001$ & 0.965 & 0.1417 \\
Branches & Ln Cbr $=-20.953+18.396 \times\left(\mathrm{DBH} \times \mathrm{H}^{-1}\right)+$ & $<0.001$ & 0.906 & 0.1042 \\
Leaves & 6.624 $\times\left(\mathrm{H} \times \mathrm{DBH}^{-1}\right)$ & $<0.001$ & 0.859 & 0.1502 \\
\hline
\end{tabular}


All models were highly significant and the assumptions of normality and homogeneity of variances were met. The coefficient estimates were also significant (branches, $p=0.019$; other components, $p<0.001)$. The equations for estimating the carbon contents of the wood components and total tree had a predictive power greater than $99.5 \%$ of the distribution of dependent variables and low standard error of estimation (0.0547 and 0.0490, respectively).

\subsection{Aboveground Carbon Concentration and Contents}

The Eucalyptus aboveground biomass contained different concentrations of organic carbon $(p \leq 0.05)$. The $\mathrm{C}$ concentration was higher in leaves, followed by branches, wood and bark (Table 4). The difference between the carbon concentration in leaves and bark was more than $100 \mathrm{~g} \mathrm{~kg}^{-1}$ biomass. Even for the highest concentration of organic carbon in leaves, the stock represented $1.6 \%$ of the total carbon stocked in the Eucalyptus aboveground biomass. The wood component accounted for more than $80 \%$ of the total carbon content of the trees, followed by the bark and branches.

Table 4. Soil, above and belowground carbon concentration, and stock in the 10-year-old Eucalyptus urophylla $\times$ Eucalyptus globulus stand. $\mu=$ average (proportion of components between brackets). $\sigma=$ standard deviation. In rows, different letters indicate significant differences for the components (Eucalyptus) and depths (fine roots and soil) at $p<0.05$ by Duncan's test. ${ }^{*}$ For litter, a carbon concentration of $50 \%$ was assumed.

\begin{tabular}{|c|c|c|c|c|c|c|c|}
\hline \multirow{2}{*}{ Components } & & \multicolumn{4}{|c|}{ Carbon Concentration (\%) } & \multicolumn{2}{|c|}{ Carbon Amount (Mg ha $\left.{ }^{-1}\right)$} \\
\hline & & $\mu$ & Lower & Higher & $\sigma$ & $\mu$ & $\sigma$ \\
\hline \multirow{5}{*}{ Eucalyptus } & Wood & $49.52 \mathrm{c}$ & 48.64 & 49.93 & 0.32 & $103.40(87.3)$ & 10.56 \\
\hline & Bark & $45.45 \mathrm{~d}$ & 43.88 & 46.23 & 0.71 & $8.57(7.2)$ & 0.76 \\
\hline & Branches & $50.41 \mathrm{~b}$ & 49.60 & 50.89 & 0.40 & $4.46(3.8)$ & 0.35 \\
\hline & Leaves & $55.66 \mathrm{a}$ & 54.48 & 56.78 & 0.57 & $2.02(1.7)$ & 0.13 \\
\hline & Total & - & - & - & - & $118.45(100)$ & 11.79 \\
\hline \multirow{4}{*}{ Understory } & Leaves & 51.38 & 49.78 & 52.26 & 0.97 & $0.18(12.7)$ & 0.22 \\
\hline & Stem & 50.02 & 48.71 & 51.09 & 0.86 & $1.26(87.3)$ & 1.35 \\
\hline & Total & - & - & - & - & $1.44(100)$ & 1.47 \\
\hline & Litter & $50 *$ & - & - & - & $8.34(100)$ & 1.75 \\
\hline \multirow{5}{*}{ Fine roots $(<2 \mathrm{~mm})$} & $0-25 \mathrm{~cm}$ & $47.68 \mathrm{a}$ & 46.98 & 48.47 & 0.75 & $0.34(69.9)$ & 0.01 \\
\hline & $25-50 \mathrm{~cm}$ & $\begin{array}{c}46.31 \\
\mathrm{ab}\end{array}$ & 44.72 & 47.37 & 1.40 & $0.09(18.3)$ & 0.04 \\
\hline & $50-75 \mathrm{~cm}$ & $44.56 \mathrm{~b}$ & 43.91 & 45.74 & 1.02 & $0.032(6.5)$ & 0.01 \\
\hline & $75-100 \mathrm{~cm}$ & $44.52 \mathrm{~b}$ & 43.41 & 45.09 & 0.96 & $0.026(5.3)$ & 0.02 \\
\hline & $0-100 \mathrm{~cm}$ & - & - & - & - & $0.48(100)$ & 0.14 \\
\hline \multirow{5}{*}{ Medium roots $(2-5 \mathrm{~mm})$} & $0-25 \mathrm{~cm}$ & 46.30 & 44.91 & 47.28 & 1.24 & $0.22(75.8)$ & 0.09 \\
\hline & $25-50 \mathrm{~cm}$ & 45.45 & 44.18 & 46.72 & 1.27 & $0.04(13.4)$ & 0.03 \\
\hline & $50-75 \mathrm{~cm}$ & 45.48 & - & - & - & $0.02(7.5)$ & 0.02 \\
\hline & $75-100 \mathrm{~cm}$ & 45.48 & - & - & - & $0.01(3.4)$ & 0.02 \\
\hline & $0-100 \mathrm{~cm}$ & - & - & - & - & $0.29(100)$ & 0.13 \\
\hline Medium roots (5-10 mm) & $0-100 \mathrm{~cm}$ & 47.24 & 46.58 & 47.90 & 0.66 & 0.17 & 0.12 \\
\hline Coarse roots $(>10 \mathrm{~mm})$ & $0-100 \mathrm{~cm}$ & 47.24 & & & & 29.11 & 2.98 \\
\hline \multirow{5}{*}{ Soil } & $0-25 \mathrm{~cm}$ & $1.23 \mathrm{a}$ & 0.80 & 1.76 & 0.32 & $43.1(43.2)$ & 10.0 \\
\hline & $25-50 \mathrm{~cm}$ & $0.97 \mathrm{~b}$ & 0.81 & 1.20 & 0.10 & $32.2(32.3)$ & 3.9 \\
\hline & $50-75 \mathrm{~cm}$ & $0.45 c$ & 0.21 & 0.70 & 0.14 & $15.5(15.5)$ & 5.4 \\
\hline & $75-100 \mathrm{~cm}$ & $0.24 \mathrm{~d}$ & 0.12 & 0.41 & 0.10 & $8.9(8.9)$ & 4.4 \\
\hline & $0-100 \mathrm{~cm}$ & - & - & - & - & $99.7(100)$ & 12.1 \\
\hline Aboveground & & - & - & - & - & $128.2(49.7)$ & - \\
\hline Belowground & & - & - & - & - & $129.8(50.3)$ & - \\
\hline Total & & - & - & - & - & $258.0(100)$ & - \\
\hline
\end{tabular}


The understory contributed $1.44 \mathrm{Mg} \mathrm{ha}^{-1}$ to the total carbon stock in the stand (Figure 2). The understory comprised herbs, shrubs, and small individuals of native tree species. The litter layer contained $8.34 \mathrm{Mg} \mathrm{ha}^{-1}$ carbon. Litter was composed of plant residues (Eucalyptus and understory) and represented $6.5 \%$ of the carbon stock in the aboveground biomass. Total carbon stock in aboveground biomass was $128.23 \mathrm{Mg} \mathrm{ha}^{-1}$, allocated in Eucalyptus biomass (92.4\%), litter (6.5\%), and understory $(1.1 \%)$.

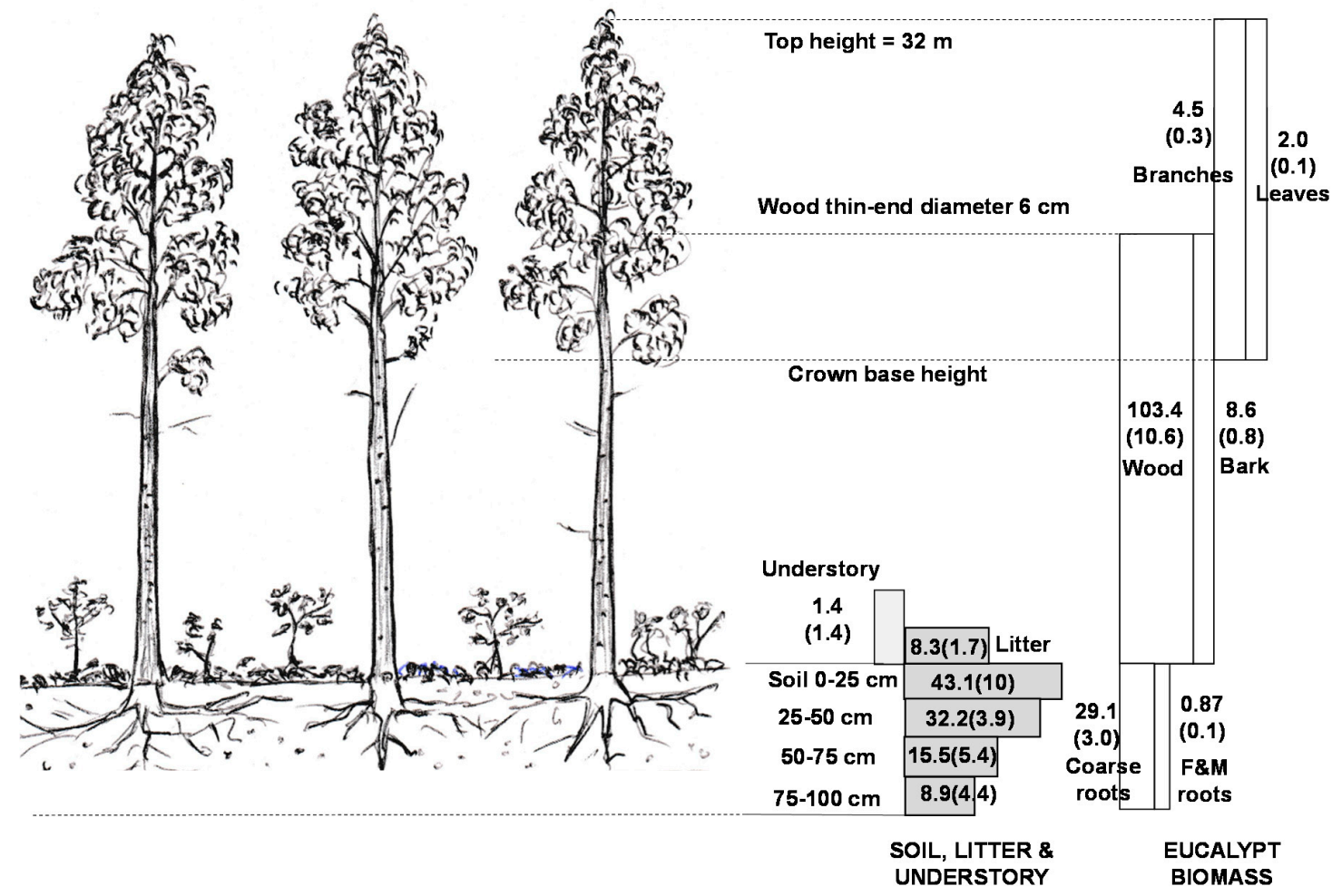

Figure 2. Illustrative carbon stock distributions $\left(\mathrm{Mg} \mathrm{ha}^{-1}\right)$ in the 10-year-old Eucalyptus urophylla $\times$ Eucalyptus globulus stand. F\&M roots = Fine + Medium roots (Prepared by the authors).

\subsection{Belowground Carbon Concentration and Contents}

The carbon concentration in the fine roots was higher $(p \leq 0.05)$ in the upper soil layer than at depths below $50 \mathrm{~cm}$. The difference between the average carbon concentrations in the roots of the upper soil layer ( 0 to $25 \mathrm{~cm}$ in depth) and the deepest layer evaluated (75 to $100 \mathrm{~cm}$ ) was more than $30 \mathrm{~g} \mathrm{~kg}^{-1}$. Almost $70 \%$ and $76 \%$ of the carbon stocks in the fine and medium roots, respectively, occurred in the upper soil layer (upper $25 \mathrm{~cm}$ ) (Table 3 and Figure 3).

The sum of the $C$ stocks in fine and medium roots was $0.95 \mathrm{Mg} \mathrm{ha}^{-1}$. The estimated $\mathrm{C}$ stock in the coarse roots was $29.11 \mathrm{Mg} \mathrm{ha}^{-1}$, with a small variation between the plots (Figure 2).

The soil organic carbon concentration was influenced by the soil depth $(p \leq 0.05)$. The carbon concentration in the upper layer was five times higher than in the deeper soil layer, directly reflecting the amount of carbon stocked in the soil. For a depth of $1 \mathrm{~m}$, more than $43 \%$ of the soil carbon stock occurred in the upper layer (depth $25 \mathrm{~cm}$ ). The total belowground carbon stock was $129.8 \mathrm{Mg} \mathrm{ha}^{-1}$ (roots + soil), corresponding to $50.3 \%$ of the carbon stocked in the Eucalyptus stand. 

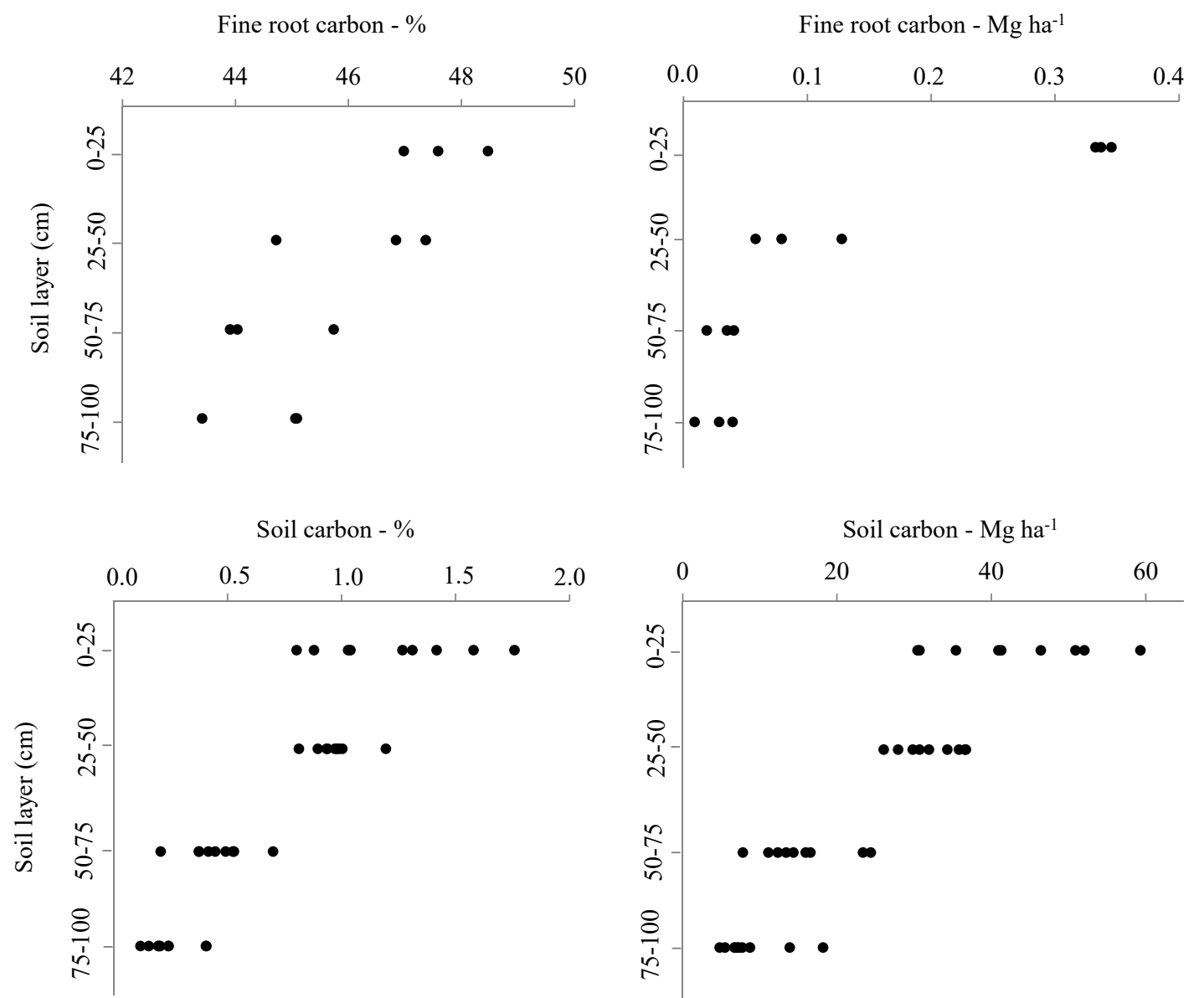

Figure 3. Carbon concentrations in the fine roots (diameter $<2.0 \mathrm{~mm}$ ) and soil and in the 10-year-old Eucalyptus urophylla $\times$ Eucalyptus globulus stand.

\section{Discussion}

The ability to measure the total amount of carbon in forest ecosystems accurately and precisely is required to evaluate the role of forests in the global carbon cycle [30]. In most forests, the largest $\mathrm{C}$ pools occurs in the aboveground live biomass and mineral soil organic matter, with smaller amounts in the roots and litter layer [31]. The most rapidly changing pool is usually the aboveground live biomass, with important differences between natural forests and forest plantations [32,33]. The size of the pool in the root biomass can be directly estimated by the average 0.26 root:shoot biomass ratio, but the soil pool is seldom related to the aboveground biomass or forest age [31].

In the present study, we determined the distribution of $C$ stocks in a stand close to rotation age. Although variations in $C$ stocks over time have not been studied, it is clear that land use change has led to an accumulation of aboveground C, resulting in a pool that is similar to that in the underground stock (including the roots and soil). Rapid accumulation of $C$ stocks in the biomass of fast growing plantations has already been noted, with estimated rates of accumulation of $8.3-12.8 \mathrm{Mg} \mathrm{C}^{-1}$ year $^{-1}$ in aboveground components reported [23]. The corresponding value determined in the present study was $11.8 \mathrm{Mg} \mathrm{C} \mathrm{ha}^{-1}$ year $^{-1}$. In the Eucalyptus aboveground biomass, the $\mathrm{C}$ was predominantly allocated in the wood, followed by the bark, branches, and leaves. This was consistent with previous findings in Eucalyptus plantations $[3,9,23]$.

The $\mathrm{C}$ concentration determined in this study was highest in the leaves, followed by the branches, wood, roots, and bark. Although this gradient has previously been reported in other Eucalyptus plantations [24,34], the present study provides complementary information such as the increase in root $\mathrm{C}$ concentration with root diameter and the decrease in $\mathrm{C}$ concentration in fine roots with soil depth. 
Carbon budgets are usually calculated on the basis of the assumption that plant biomass is $50 \%$ C. For this study, the weighted average for Eucalyptus biomass was 48.9\%. Thus, the general application of $50 \% \mathrm{C}$ to all components would lead to a slight over-prediction of $3.4 \mathrm{Mg} \mathrm{C} \mathrm{ha}^{-1}$ (relative error of $2.3 \%$ ). Weighted averages of $47.7 \%$ for the aboveground biomass of E. globulus and E. nitens in Spain [12] and $49.77 \%$ for the above and belowground components of the same species in Tasmania [35] have previously been reported.

The understory biomass is not usually considered in studies of carbon fixation in fast-growing plantations. In the present study, we found that more than $1 \%$ of the total carbon stocked in the aboveground biomass was in the understory and that the $\mathrm{C}$ concentration in this ecosystem component was slightly higher than $50 \%$ (weighted average, $50.2 \%$ ). In a study carried out in a E. urophylla $\times$ E. grandis stand of age 6-8 years in China, about $2 \%$ of the aboveground carbon was fixed in the understory biomass [3]. The relatively small amount of carbon found in the understory in the present study can be explained by the full canopy cover (leaf area index of $2.55 \mathrm{~m}^{2} \mathrm{~m}^{-2}$ ) of the plantation. Nonetheless, relative to the previous land use (pasture), afforestation has led to the presence of an understory of native trees.

Fine and medium roots thinner than $10 \mathrm{~mm}$ contributed $0.95 \mathrm{Mg} \mathrm{ha}^{-1}$ to the total $\mathrm{C}$ stock. More than $70 \%$ of the carbon stock in the fine and medium roots occurred in the topsoil $(25 \mathrm{~cm} \mathrm{deep})$ where the highest $C$ concentration in fine roots occurred. Considering the estimated amount of $C$ in the coarse roots and stump, the root:shoot ratio for $C$ stocks obtained in this study was 25.4, with a biomass root:shoot ratio of 26.5, a value close to that reported for allometric biomass relationships in angiosperms worldwide [36]. This indicates the importance of the accurate estimation of coarse root biomass for calculating the total ecosystem $C$ budgets [35]. Tree root systems represent an important component of forest ecosystems because they absorb water and soil nutrients, thus supporting the arboreal structure and function as a store of nutrients and carbon [37,38]. Previous estimations of root C stocks in 8-year-old plantations in the same regions of this study provided values $\geq 10 \mathrm{Mg} \mathrm{ha}^{-1}$ [39].

In the present study, 38.6\% of the total organic carbon in the Eucalyptus plantations occurred in the soil. In a study of other Eucalyptus plantations aged seven years, the ratio between the organic carbon in the soil (to a depth of $100 \mathrm{~cm})$ and the total carbon was found to be greater $(43 \%-63 \%)$ [40]. Soil organic matter comprises the largest $C$ pool in many natural forests, but the aboveground biomass C pool is the predominant pool in forest plantations [31], as observed in the present study. Moreover, important losses of soil organic carbon occur in the upper mineral soils during the first decade after afforestation [41]. Such losses are common in afforested grassland soils under humid temperate climates [42] and occur as a consequence of mineralization of the labile fraction produced by soil disturbance during planting, even when minimum tillage is applied. Although we were not able to assess such losses in this study, this effect should be considered when land use changes are proposed.

The depth at which the soil is sampled is an important source of uncertainty in the determination of total C in forest ecosystems as forest soils are often very deep (several meters) [17]. The concentration of soil organic carbon (SOC) is influenced by the soil depth due to variations in organic matter. The carbon concentration in the upper soil layer found in this study was five times higher than in the deeper soil layers. Higher concentrations of carbon in the upper soil layers have generally been reported for other forest ecosystems, e.g., [3,6,40,43]. Most of the soil carbon in forest plantations (i.e., about 57\% to $68 \%$ ) has previously been detected in the upper $50 \mathrm{~cm}$ of soil $[3,7,44]$. This layer represented more than $75 \%$ of the soil carbon stock occurring within a depth of one meter in the present study. These results indicate the need to lengthen the rotations or make appropriate decisions at harvesting to prevent net soil $\mathrm{C}$ emissions due to soil disturbances during the operations.

The total C stored in the plantation under study was $258 \mathrm{Mg} \mathrm{ha}^{-1}$. This was much lower than the high biomass carbon densities found in native and older forests that are multi-aged, multilayered, and have been subjected to minimal human disturbance [45]. It is clear that protecting forests with large biomass stocks from deforestation and degradation (including transformation into plantations) prevents the release of significant carbon emissions into the atmosphere [46]. Plantations such as that 
considered in the present study are often established on former pasture land for the main purpose of the sustainable production of fiber, timber, and energy. The findings of the present and previous studies show that plantations, if adequately managed, can provide carbon sequestration as an important environmental service.

\section{Conclusions}

The total C stock in a fast growing $\left(36.7 \mathrm{~m}^{3} \mathrm{ha}^{-1}\right.$ year $\left.{ }^{-1}\right)$ Eucalyptus plantation aged 10 years (biomass + soil) was $258 \mathrm{Mg} \mathrm{ha}^{-1}$ and was distributed between the aboveground (49.7\%) and belowground (50.3\%) components. The above and belowground eucalypt biomass accounted for $57.6 \%$ of total C, whereas the share of the wood component alone was $40 \%$. Soil represented an important component, accumulating 38.6\% of the total $\mathrm{C}$, mainly in the upper $25 \mathrm{~cm}$. Litter and understory represented $3.2 \%$ and $0.6 \%$ of the total $C$, respectively. Plantations established for the sustainable production of goods can provide $\mathrm{C}$ accumulation as an important ecosystem service at a rate of $11.8 \mathrm{Mg} \mathrm{ha}^{-1}$ year $^{-1}$ (eucalyptus aboveground biomass) or $14.8 \mathrm{Mg} \mathrm{ha}^{-1}$ year $^{-1}$ (including the root system).

Author Contributions: M.V. devised the project, performed the experiments, analyzed the data and drafted the manuscript. R.R.-S. performed additional analysis of data and discussed the results. Both authors contributed to the final version of the manuscript.

Funding: The National Council of Technological and Scientific Development (CNPq-Brazil) awarded the first author with a research grant (Award Number 200589/2014-8) for a one-year stay at the USC in Spain.

Acknowledgments: We thank the CMPC pulp company for making the study area available and for their logistical support. We also thank Mauro Valdir Schumacher and Peter Trüby for helping with the carbon determination.

Conflicts of Interest: The authors declare no conflict of interest. The funders had no role in the design of the study; in the collection, analysis or interpretation of data; in the writing of the manuscript, or in the decision to publish the results.

\section{References}

1. IBGE. Instituto Brasileiro de Geografia e Estatística. Produção da extração vegetal e da silvicultura. IBGE 2017, 32, 1-8.

2. IBA. Brazilian Tree Industry; Report 2015; IBÁ: São Paulo, Brazil, 2015; 64p.

3. Du, H.; Zeng, F.; Peng, W.; Wang, K.; Zhang, H.; Liu, L.; Song, T. Carbon storage in a Eucalyptus plantation chronosequence in Southern China. Forests 2015, 6, 1763-1778. [CrossRef]

4. Volkova, L.; Bi, H.; Murphy, S.; Weston, C.J. Empirical estimates of aboveground carbon in open Eucalyptus forests of south-eastern Australia and its potential implication for national carbon accounting. Forests 2015, 6, 3395-3411. [CrossRef]

5. Fialho, R.C.; Zinn, Y.L. Changes in soil organic carbon under Eucalyptus plantations in Brazil: A comparative analysis. Land Degrad. Dev. 2014, 25, 428-437. [CrossRef]

6. Justine, M.F.; Yang, W.; Wu, F.; Tan, B.; Khan, M.N.; Zhao, Y. Biomass stock and carbon sequestration in a chronosequence of Pinus massoniana plantations in the upper reaches of the Yangtze River. Forests 2015, 6, 3665-3682. [CrossRef]

7. Cook, R.L.; Binkley, D.; Stape, J.L. Eucalyptus plantation effects on soil carbon after 20 years and three rotations in Brazil. For. Ecol. Manag. 2016, 359, 92-98. [CrossRef]

8. Sausen, T.L.; Schaefer, G.F.P.; Tomazi, M.; Santos, L.S.; Bayer, C.; Rosa, L.M.G. Clay content drives carbon stocks in soils under a plantation of Eucalyptus saligna Labill. in southern Brazil. Acta Bot. Bras. 2014, 28, 266-273. [CrossRef]

9. Vallejos-Barra, O.; Daniluk-Mosquera, G.; Moras, G.; Ponce-Donoso, M.; Conteras, M.A. Above-ground carbon absorption in young Eucalyptus globulus plantations in Uruguay. Sci. For. 2014, 42, 9-19.

10. Jackson, R.B.; Avissar, R.; Baidya, R.S.; Barrett, D.J.; Cook, C.W.; Farley, K.A.; LeMaitre, D.C.; McCarl, B.A.; Murray, B.C. Trading water for carbon with biological carbon sequestration. Science 2005, 310, 1944-1947. [CrossRef] 
11. Farley, K.A.; Jobbágy, E.G.; Jackson, R.B. Effects of afforestation on water yield: A global synthesis with implications for policy. Glob. Change Biol. 2005, 11, 1565-1576. [CrossRef]

12. Rodríguez-Soalleiro, R.; Eimil-Fraga, C.; Gómez-García, E.; García-Villabrille, J.D.; Rojo-Alboreca, A.; Muñoz, F.; Oliveira, N.; Sixto, H. Exploring the factors affecting carbon and nutrient concentrations in tree biomass components in natural forests, forest plantations and short rotation forestry. For. Ecosyst. 2018, 5, 35. [CrossRef]

13. Ryan, M.G.; Stape, J.L.; Binkley, D.; Fonseca, S.; Loos, R.A.; Takahashi, E.N.; Silva, C.R.; Silva, S.R.; Hakamada, R.E.; Ferreira, J.M.; et al. Factors controlling Eucalyptus productivity: How resource availability and stand structure alter production and carbon allocation. For. Ecol. Manag. 2010, 259, 1695-1703. [CrossRef]

14. Liski, J.; Pussinen, A.; Pingoud, K.; Mäkipää, R.; Karjalainen, T. Which rotation length is favourable to carbon sequestration? Can. J. For. Res. 2001, 31, 2004-2013. [CrossRef]

15. Maquere, V.; Laclau, J.P.; Bernoux, M.; Saint-Andre, L.; Gonçalves, J.L.M.; Cerri, C.C.; Piccolo, M.C.; Ranger, J. Influence of land use (savanna, pasture, Eucalyptus plantations) on soil carbon and nitrogen stocks in Brazil. Eur. J. Soil Sci. 2008, 59, 863-877. [CrossRef]

16. Don, A.; Schumacher, J.; Freibauer, A. Impact of tropical land-use change on soil organic carbon stocks - a meta-analysis. Glob. Chang. Biol. 2010, 17, 1658-1670. [CrossRef]

17. Lal, R. Forest soils and carbon sequestration. For. Ecol. Manag. 2005, 220, 242-258. [CrossRef]

18. Karvonen, J.; Halder, P.; Kangas, J.; Leskinen, P. Indicators and tools for assessing sustainability impacts of the forest bioeconomy. For. Ecosyst. 2017, 4, 2. [CrossRef]

19. Marasemi, T. Special Issue Information Forest Carbon Inventories and Management. 2019. Available online: https://www.mdpi.com/journal/forests/special_issues/Forest_Carbon_Inventories (accessed on 10 April 2019).

20. Lima, A.M.N.; Silva, I.R.; Neves, J.C.L.; Novais, R.F.; Barros, N.F.; Mendonca, E.S.; Smyth, T.J.; Moreira, M.S.; Leite, F.P. Soil organic carbon dynamics following afforestation of degraded pastures with Eucalyptus in southeastern Brazil. For. Ecol. Manag. 2006, 235, 219-231. [CrossRef]

21. Stape, J.L.; Bincley, D.; Ryan, M.G. Production and carbon allocation in a clonal Eucalyptus plantation with water and nutrient manipulations. For. Ecol. Manag. 2008, 255, 920-930. [CrossRef]

22. Trugilho, P.F.; Arantes, M.D.C.; Pádua, F.A.; Almado, R.P.; Ana, E.R.B. Estimativa de carbono na madeira de um clone híbrido de Eucalyptus urophylla e Eucalyptus grandis. Cerne 2010, 16, 33-40.

23. Gatto, A.; Barros, N.F.; Novais, R.F.; Silva, I.R.; Leite, H.G.; Villani, E.M.A. Estoque de carbono na biomassa de plantações de eucalipto na região centro-leste do estado de Minas Gerais. Rev. Árvore 2011, 35, 895-905. [CrossRef]

24. Silva, C.A.; Klauberg, C.; Carvalho, S.P.C.; Piccolo, M.C.; Rodriguez, L.C.E. Estoque de carbono na biomassa aérea florestal em plantações comerciais de Eucalyptus spp. Sci. For. 2015, 43, 135-146.

25. Yang, L.; Wang, J.; Huang, Y.; Hui, D.; Wen, M. Effects of the Interception of Litterfall by the Understory on Carbon Cycling in Eucalyptus Plantations of South China. PLoS ONE 2014, 9, e100464. [CrossRef] [PubMed]

26. Alvares, C.A.; Stape, J.L.; Sentelhas, P.C.; Gonçalves, J.L.M.; Sparovek, G. Köppen's climate classification map for Brazil. Meteorol. Z. 2013, 22, 711-728. [CrossRef]

27. Food and Agriculture Organization of the United Nations. World Reference Base for Soil Resources: A Framework for International Classification, Correlation and Communication; FAO: Rome, Italy, 2014; 192p.

28. Stape, J.L.; Binkley, D.; Ryan, M.G. Eucalyptus production and the supply, use and efficiency of use of water, light and nitrogen across a geographic gradient in Brazil. For. Ecol. Manag. 2004, 193, 17-31. [CrossRef]

29. SPSS. Statistical Package for the Social Sciences: Programa de Computador, Ambiente Windows; Versão 7.5.1; IBM: Chicago, IL, USA, 1996.

30. Brown, S. Measuring carbon in forests: current status and future challenges. Environ. Pollut. 2002, 116, 363-372. [CrossRef]

31. Fahey, T.J.; Woodbury, P.B.; Battles, J.J.; Goodale, C.L.; Hamburg, S.P.; Ollinger, S.V.; Woodall, C.W. Forest carbon storage: Ecology, management, and policy. Front. Ecol. Environ. 2010, 8, 245-252. [CrossRef]

32. IPCC. Forest Land. In Guidelines for National Greenhouse Gas Inventories. Volume 4: Agriculture, Forestry and Other Land Use; Cambridge University Press: Cambridge, UK; New York, NY, USA, 2006.

33. Mancini, M.S.; Galli, A.; Niccolucci, V.; Lin, D.; Bastianoni, S.; Wackernagel, M.; Marchettini, N. Ecological Footprint: Refining the carbon Footprint calculation. Ecol. Indic. 2016, 61, 390-403. [CrossRef]

34. Dallagnol, F.S.; Mognon, F.; Sanquetta, C.R.; Corte, A.P. Teores de carbono de cinco espécies florestais e seus compartimentos. Floresta Ambient. 2011, 18, 410-416. [CrossRef] 
35. Resh, S.C.; Battaglia, M.; Worledge, D.; Ladiges, S. Coarse root biomass for eucalypt plantations in Tasmania, Australia: Sources of variation and methods for assessment. Trees 2003, 17, 389-399. [CrossRef]

36. Enquist, B.J.; Niklas, K.J. Global allocation rules for patterns of biomass partitioning in seed plants. Science 2002, 295, 1517-1520. [CrossRef]

37. Tang, G.; Li, K.; Zhang, C.; Gao, C.; Li, B. Accelerated nutrient cycling via leaf litter, and not root interaction, increases growth of Eucalyptus in mixed-species plantations with Leucaena. For. Ecol. Manag. 2013, 310, 45-53. [CrossRef]

38. Huang, X.; Liu, S.; Wang, H.; Hu, Z.; Li, Z.; You, Y. Changes of soil microbial biomass carbon and community composition through mixing nitrogen-fixing species with Eucalyptus urophylla in subtropical China. Soil Biol. Biochem. 2014, 73, 42-48. [CrossRef]

39. Schumacher, M.V.; Witschoreck, R. Inventário de Carbono em Povoamentos de Eucalypus spp nas Propriedades fumageiras do sul do Brasil: "Um Estudo de caso". In Fixação de Carbono: Atualidades, Projetos e Pesquisas; Sanquetta, C.R., Balbinot, R., Ziliotto, M.A.B., Eds.; AM Impressos: Curitiba, Brazil, 2004; pp. 111-124.

40. Gatto, A.; Barros, N.F.; Novais, R.F.; Silva, I.R.; Leite, H.G.; Leite, F.P.; Villani, E.M.A. Estoques de carbono no solo e na biomassa em plantações de eucalipto. R. Bras. Ci. Solo 2010, 34, 1069-1079. [CrossRef]

41. Pérez-Cruzado, C.; Mansilla, P.; Rodríguez-Soalleiro, R.; Merino, A. Influence of tree species on carbon sequestration in afforested pastures in a humid temperate region. Plant Soil 2002, 353, 333-353. [CrossRef]

42. Kirschbaum, M.U.F.; Guo, L.B.; Gifford, R.M. Why does rainfall affect the trend in soil carbon after converting pastures to forests? A possible explanation based on nitrogen dynamics. For. Ecol. Manag. 2008, 255, 2990-3000. [CrossRef]

43. De Koning, G.H.J.; Veldkamp, E.; López-Ulloa, M. Quantification of carbon sequestration in soils following pasture to forest conversion in northwestern Ecuador. Glob. Biogeochem. Cycles 2003, 17, 1098. [CrossRef]

44. Madeira, M.V.; Fabião, A.; Pereira, J.S.; Araújo, M.C.; Ribeiro, C. Changes in carbon stocks in Eucalyptus globulus Labill, plantations induced by different water and nutrient availability. For. Ecol. Manag. 2002, 171, 75-85. [CrossRef]

45. Keith, H.; MacKey, B.G.; Lindenmayer, D.B. Re-evaluation of forest biomass carbon stocks and lessons from the world's most carbon-dense forests. Proc. Natl. Acad. Sci. 2009, 106, 11635-11640. [CrossRef]

46. Canadell, J.G.; Raupach, M.R. Managing forests for climate change mitigation. Science 2008, 320, $1456-1457$. [CrossRef]

(C) 2019 by the authors. Licensee MDPI, Basel, Switzerland. This article is an open access article distributed under the terms and conditions of the Creative Commons Attribution (CC BY) license (http://creativecommons.org/licenses/by/4.0/). 